\title{
Polícia e exclusão na cultura judiciária
}

\author{
ROBERTO KANT DE LIMA
}

\begin{abstract}
RESUMO: O trabalho pretende argumentar que o papel institucional da polícia é influenciado pela posição particular que a instituição policial ocupa formal e informalmente no sistema judiciário. Ao contrário das concepções que vêem a polícia como encarregada do exercício de formas de controle social preventivo e portanto com autonomia frente à Promotoria e ao Judiciário, também será mostrado que esta posição institucional está relacionada às diferentes formas de produção de verdades judiciárias válidas para o sistema judiciário criminal de cada país.
\end{abstract}

\section{Apresentação}

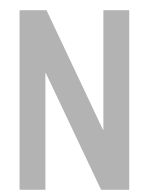

este trabalho, pretendo argumentar que o papel institucional da polícia, é, senão definido, pelo menos fortemente influenciado pela posição extremamente particular que a instituição policial ocupa, formal e informalmente, no sistema judiciário. Contrariamente às concepções que vêem a polícia como encarregada, principalmente, do exercício de formas de controle social preventivo e, assim, dotada de relativa autonomia frente à promotoria e ao Judiciário, também argumentarei que esta posição institucional está relacionada às diferentes formas de produção de verdades judiciárias válidas para o sistema judiciário criminal de cada país.

Para isto, deverei explicitar certas características de nosso sistema judiciário, contrastando-o com o dos Estados Unidos da América, mostrando, por exemplo, como a ênfase brasileira na supressão e punição dos conflitos e a ênfase dos EUA na sua resolução e controle produzem diferentes efeitos na atividade policial e como a forma hierárquica e excludente com que se estrutura internamente nossa polícia afeta seu desempenho funcional e suas relações com a população.
UNITERMOS: organização policial, sistema judiciário, cultura, controle social, inquérito policia, processo judicial.

Professor do Departamento de Antropologia da UFF 
Utilizarei dados recolhidos em pesquisa realizada por mim e pelo grupo de pesquisa que coordeno, no CNPq e na Pós-Graduação em Antropologia e Ciência Política da Universidade Federal Fluminense. A coleta de dados envolveu pesquisa arquivística e trabalho de campo com instituições policiais e judiciárias do Brasil e dos EUA, realizada nos últimos 15 anos, nas cidades do Rio de Janeiro e Niterói, no Brasil, e em Birmingham, Alabama e San Francisco, Califórnia, nos EUA, com recursos da UFF, CAPES, CNPq, USIS e Comissão Fulbright.

A análise e interpretação destes dados, além de vários artigos e capítulos de livros publicados em revistas, no Brasil e no exterior, resultaram no livro, A polícia da cidade do Rio de Janeiro: seus dilemas e paradoxos (Forense) e em tese aprovada no concurso de titular em Antropologia da UFF, "Da inquirição ao júri, do trial by jury à plea bargain: modelos para a produção da verdade e a negociação da culpa em uma perspectiva comparada (Brasil/ EUA)", que está no prelo para ser publicada pela Editora da Universidade Federal Fluminense (EDUFF).

A perspectiva que se adotou na apresentação desses dados foi ditada pelo uso do método comparativo como em voga na tradição antropológica contemporânea, que enfatiza as diferenças e as descontinuidades, mais que as semelhanças e as continuidades, entre os sistemas de justiça criminal estudados. Tal ponto de vista pode ser responsabilizado pela maior parte das polêmicas geradas por seus resultados, tanto no que diz respeito a sua validade e abrangência, quanto a sua contraposição a outros usos do método comparativo correntes na ciência política e no direito que, enfatizando semelhanças, costumam classificar as diferenças empíricas de acordo com um sistema de referências pré-estabelecido, o que resulta exatamente naquilo que aqui se quer evitar: classificá-las como piores ou melhores, independentemente de seu contexto.

Acredito que eventuais discussões geradas por este ponto de vista possam ser úteis na elucidação de certas características de nosso sistema de justiça criminal, subsidiando, direta ou indiretamente, a formulação de políticas que visem sua alteração eficaz, cumprindo, assim, o papel que a tradição antropológica tem desempenhado em processos semelhantes de mudança social, cultural e institucional.

\section{O sistema judiciário penal como um sistema de administração de conflitos pela produção de verdades}

O sistemas judiciários tem uma de suas principais ênfases $\mathrm{Na}$ administração de conflitos na sociedade. Entretanto, não são unânimes as formas que sua administração deve tomar, pois estão relacionadas a diferentes tradições culturais que, por exemplo, ora vêem nos conflitos fonte de desordem e de quebra da harmonia social, a ser reprimida ou exemplarmente punida, ora vêem nos conflitos, considerados inevitáveis para a vida social, fonte de 
ordem quando devidamente solucionados.

Assim, instituem-se verdadeiros sistemas de verdade ou regimes de verdade, que são responsáveis pela produção das prestações judiciárias encarregadas de administrar conflitos. Normalmente, tais regimes são apresentados como tendo se sucedido no tempo, a existência de um eliminando a existência do outro. Argüirei aqui que isto não é necessariamente verdadeiro, tomando como exemplo o sistema judiciário criminal brasileiro, no qual diferentes sistemas convivem, de forma mais ou menos explícita, concomitantemente, e são alternadamente utilizados pelos operadores judiciais.

Ora, se isso é verdade, embora o sistema jurídico continuasse a afirmar seu caráter universalista na aplicação das mesmas regras a todos, esta concomitância e a possibilidade implícita de alternância, implicaria, certamente, a aplicação de diferentes regras a diferentes "casos" ou a diferentes "partes" em conflitos semelhantes a serem igualmente administrados pelo mesmo Estado.

Para levar esta tarefa a bom termo, será necessário estabelecer certas referências comparativas, que coloquem em contraste diferentes sistemas judiciários - sistemas de produção de provas ou de verdades judiciárias. Para o propósito desta comunicação, deverei tomar os sistemas de justiça criminal do Brasil e dos EUA como referências. De novo, devo enfatizar que a perspectiva comparada que pretendo utilizar será de caráter contrastivo, buscando as diferenças e, não, as possíveis semelhanças entre os sistemas, para perceber, dentro de suas especificidades, suas equivalências enquanto sistemas de produção de verdades judiciárias. Isto quer dizer que comportamentos, instituições e categorias semelhantes podem ter diferentes significados e papéis; e, vice-versa, elementos diferentes podem ter papéis e significados semelhantes.

Finalmente, devo novamente insistir em que interessa ao antropólogo compreender e explicitar os princípios de funcionamento dos diferentes sistemas ou regimes de verdade, não estando em pauta, aqui, o julgamento de qual sistema é superior, ou inferior, ao outro.

\section{A referência comparativa}

O regime de verdade do criminal justice system dos EUA repousa sobre a idéia de que a verdade é fruto de uma decisão consensual sistematicamente negociada. Isto vale tanto para a barganha que se faz entre a promotoria e a defesa, quando o réu se declara culpado - plea guilty, plea bargainquanto para a decisão que encerra a arbitragem, pelo judiciário, dos conflitos em que o réu insiste em se declarar não culpado - not guilty. Neste último caso, constrói-se também a verdade pela negociação, pois o verdict nada mais é do que uma decisão tomada por maioria ou por unanimidade dos jurados, que a negociam discutindo entre si até chegarem a uma conclusão satisfatória para todos. 
Então, a verdade pública produzida para administrar conflitos é, explicitamente, fruto (a) de uma negociação patrocinada pelo District Attorney Office (promotoria) - uma barganha em que cada uma das partes desiste de sua verdade para compor uma terceira versão satisfatória para todos - ou (b) de uma negociação no âmbito do judiciário, entre os jurados, árbitros selecionados pelas partes para decidir qual a verdade que vão dizer ao público, depois de presenciarem a exposição dos fatos admitidos em juízo - seu verdict (vere dictum).

Este último sistema, no âmbito do judiciário dos EUA, é denominado de trial by jury e é considerado um desdobramento - ou, como costumam dizer os juristas, de maneira equivocada, uma "evolução" de outros sistemas judiciários, que tinham ou no sistema de "prova legal", ou no "inquest", seus principais fundamentos.

Como se sabe, o sistema de "prova legal" era uma espécie de regulação da guerra, em que não importavam os fatos ou testemunhos do conflito, mas a escolha divina de uma das partes como vencedora de um determinado teste. Já o inquest - ou inquisitio - era um sistema - denominado de "racional" por oposição ao da "prova legal" - em que eram tomados testemunhos em interrogatórios de resposta obrigatória para aqueles que tinham conhecimento dos fatos.

Ora, a tradição judicial dos EUA considera que esses dois sistemas de verdade foram substituídos lá, por um terceiro, de arbitragem pelo júri. São características deste sistema a presunção da inocência - pois só vão a julgamento os acusados que não se declaram culpados; o direito de não se incriminar, que impõe ao silêncio o significado da não culpabilidade, tendo como correlata a obrigação de dizer a verdade - tudo o que todos dizem em juízo deve ser verdade, sob pena de cometerem o crime de perjury; e a escolha em comum acordo dos "fatos" que devem ser discutidos e validados diante dos jurados, excluindo-se aqueles que não são consensualmente aprovados, através das exclusionary rules. O procedimento é todo oral e as falas são transcritas literalmente, servindo, a partir daí, de documentos para futuras discussões em outras instâncias. A oralidade, a explicitude e a literalidade são as suas características.

Por outro lado, o sistema do D.A. também é considerado um desdobramento do direito de os cidadãos negociarem com o Estado sua culpa, quando o desejassem, uma vez que a promoção das acusações durante muito tempo não foi obrigatória no sistema judiciário dos EUA. Tanto a polícia, como a promotoria, têm o direito - e o dever-de barganhar com os acusados, pressionando-os para se declararem culpados de um crime menor sob a ameaça de serem levados a juízo por um crime maior e correrem o risco de serem por este condenados. A justificativa explícita deste procedimento é a sua "economia processual", pois a arbitragem pelo júri é muito dispendiosa para o judiciário e para as partes. O que está em jogo, portanto, não é o que os acusados efetivamente fizeram, mas quais as suas possibilidades de negociação com o 
sistema. Além disso, embora a promoção não seja mais facultativa ao executivo, a promotoria só acusa quando acha que pode vencer o caso. Caso contrário, não deve tomar a iniciativa de promover a arbitragem pelo judiciário.

O mais importante para reter, no entanto, é que apesar das diversas críticas que este sistema sofre, seja por ser mais injusto com as partes mais fracas, seja por apresentar soluções diferentes para conflitos através de duas instituições, o judiciário - com seu due process of law - e a promotoria e a polícia - com as suas diferentes bargains - é que a sua lógica é una e inequívoca: a verdade pública é fruto de uma negociação sistemática entre as partes interessadas.

\section{0 sistema judiciário criminal brasileiro: características gerais}

Ora, por contraste com esta lógica unívoca, o sistema brasileiro nos apresenta um mosaico de "sistemas de verdade", tanto em suas disposições constitucionais, como em suas disposições judiciárias e policiais. Mais ainda, por não reconhecer, explicitamente, que tais sistemas existem, o sistema judicial criminal permite que estas diferentes lógicas sejam usadas alternativa e alternadamente, embora as verdades por elas produzidas se desqualifiquem umas às outras, o que redunda em verdadeira "dissonância cognitiva", tanto para os operadores do sistema como para a população em geral.

Estas diferentes disposições podem coexistir porque, por um artifício da chamada "dogmática jurídica", uma espécie de doutrina jurídica, as normas jurídicas encontram-se hierarquizadas e se anulam automática e reciprocamente quando entram em contradição, observando-se, para resolver os conflitos entre elas, a rígida hierarquia em que, teoricamente, se encontram dispostas.

Essa doutrina, portanto, como todo conhecimento dogmático, não deixa espaço para que se explicitem as diferentes tradições e a sua história, que imprimem significados distintos a procedimentos semelhantes.

No topo desta hierarquia de normas temos os princípios constitucionais. Estes, aparentemente, são assemelhados àqueles do due process of law dos EUA: asseguram a presunção da inocência, o direito à defesa - chamado de princípio do contraditório - assegurando, entretanto, um outro direito, chamado de ampla defesa, pelo qual os acusados podem e devem usar todos os recursos possíveis em sua defesa. Note-se, também, que está assegurado constitucionalmente o direito de o acusado não se auto-incriminar (direito ao silêncio), mas não se incrimina, como no direito angloamericano, a mentira dita pelo réu em sua defesa.

A seguir, temos o Código de Processo Penal, que regula três formas de produção da verdade: a policial, a judicial e a do Tribunal do Júri. Tais formas encontram-se, no Código, hierarquizadas explicitamente: no inquérito policial o procedimento da polícia judiciária é "administrativo" e não judicial e, por isso, não se rege pelo princípio do contraditório; o procedimento judi- 
cial aplica-se à maioria dos crimes, e inicia-se, obrigatoriamente, quando há indícios suficientes de que um delito foi cometido e que sua autoria é presumida, com a denúncia da promotoria dando oportunidade à defesa, pois se regula pelo princípio do contraditório; $\mathrm{e}$, finalmente, o julgamento pelo Tribunal do Júri é um procedimento que se aplica apenas aos crimes intencionais contra a vida humana e se inicia por uma sentença judicial proferida por um juiz (pronúncia), após a realização da produção de provas durante a instrução judicial, comum a todos os processos judiciais criminais e também regida pelo contraditório e pela ampla defesa. Há outros procedimentos, vinculados à natureza das infrações, que deixo para analisar em outra oportunidade.

Em sua Exposição de Motivos, o Código de Processo Penal também explica que o objetivo do processo judicial criminal é a descoberta da "verdade real", por oposição à "verdade formal" do processo civil, quer dizer, aquela que é levada ao juiz, por iniciativa das partes. Por isso, os juízes podem e devem tomar a iniciativa de trazer aos autos tudo o que pensarem interessar ao processo, ex-officio, para formar o seu "livre convencimento" examinando a "prova dos autos", quer dizer, todos os elementos que se encontram registrados, por escrito, nos volumes que formam os processos judiciais e os inquéritos policiais. Além disso, não há, no direito brasileiro, uma hierarquia explícita e obrigatória de provas, podendo ser examinadas todas as que vierem ao processo, inclusive as resultantes não só da iniciativa do juiz, como das partes, no exercício do direito constitucional de "ampla defesa".

\section{a. $O$ inquérito policial}

De acordo com um delegado de polícia, entrevistado durante a pesquisa, o inquérito policial é "um procedimento do Estado contra tudo e contra todos para apurar a verdade dos fatos". Assim, o inquérito policial é um procedimento no qual quem detém a iniciativa é um Estado imaginário, todo poderoso, onipresente e onisciente, sempre em sua busca incansável da verdade, representado pela autoridade policial, que, embora sendo um funcionário do Executivo, tem uma delegação do judiciário e a ele está subordinado quando da realização de investigações.

O procedimento judiciário policial, portanto, pode ser inquisitorial, sem contraditório, porque ainda não há acusação. Entretanto, embora não seja legalmente permitida a negociação da culpa, ou da verdade, neste nível - como, aliás, em nenhum nível do processo criminal, que está em busca da "verdade real", como se viu -é lógico que a polícia barganhe, negocie, oficiosa e/ou ilegalmente, em troca de algum tipo de vantagem, tanto o que investiga como o que os escrivães policiais escrevem nos "autos" do inquérito policial, o que se denomina, mesmo, por uma categoria específica: a "armação do processo".

Tais procedimentos, sempre ameaçados de ilegalidade, são sempre analisados ou como distorções, ou como desvios de comportamento, atribuídos a funcionários inescrupulosos. Entretanto, embora isto possa ser em al- 
guns casos verdade, observei durante a pesquisa de campo certas regularidades que apontam para a consistência de tais procedimentos com um verdadeiro sistema de produção de verdade, de eficácia comprovada. Assim, a regulação da tortura de acordo com a gravidade da denúncia ou queixa e conforme a posição social dos envolvidos; a permissão da participação dos advogados nos inquéritos também de acordo com as diferentes posições que estes especialistas ocupam nos quadros profissionais; a qualificação e tipificação das infrações e crimes registrados e o arquivamento ou prosseguimento do inquérito policial de acordo com interesses manifestamente particulares são, sem dúvida, algumas dessas práticas institucionalizadas.

Ora, muito depois de ter tido contato com tais práticas durante o trabalho de campo, pesquisas arquivísticas complementares, orientadas por colegas especialistas em história do processo, mostraram que os procedimentos observados eram muito semelhantes aos da "inquirição-devassa" do direito português ou da "inquisitio" do direito canônico: um procedimento sigiloso, que preliminarmente investiga, sem acusar, visando obter informações sobre perturbações da ordem denunciadas pública ou anonimamente; depois, averiguados os fatos, chama o suposto responsável para interrogá-lo, perguntando-lhe sobre o que já se sabe sobre ele, objetivando levá-lo a confessar; se o crime é leve e o acusado confessa, é repreendido, apenas; se o acusado não confessa, ou se o crime é grave, o acusado é "indiciado" e o processo é encaminhado à justiça criminal, para que o promotor promova a "denúncia" do indiciado, agora "réu".

Estes procedimentos se justificavam em sociedades nas quais a desigualdade substantiva entre as partes era explícita: não se desejava manchar a reputação de homens de honra que podiam ser injustamente acusados, nem se desejava expor os despossuídos à ira dos poderosos por eles denunciados: o Estado, então, compensava essa desigualdade, assumindo a iniciativa da descoberta da verdade. Aqui, é evidente a produção de um ethos de suspeição sistemática motivado pelo desejo de evitar ou abafar os conflitos ou de punir aqueles que neles se envolvem, prejudicando a harmonia de uma sociedade na qual cada um tem o seu lugar.

\section{b. O processo judicial}

Já vimos que o processo judicial se inicia pela denúncia do promotor - uma acusação pública que gera defesa - seguindo-se o interrogatório do réu. Neste interrogatório defesa e acusação não participam, ou participam apenas como assistentes. É um procedimento nitidamente inquisitorial, em que o juiz adverte, obrigatoriamente, o acusado de que "seu silêncio poderá resultar em prejuízo de sua própria defesa”, algo que parece colocar-se nitidamente em contradição com o direito ao silêncio do dispositivo constitucional.

Em compensação, se o silêncio pode vir em prejuízo da própria defesa, o réu pode mentir livremente, pois apenas as pessoas arrependidas 
confessam a verdade. O crime de "falso testemunho", diferentemente do crime de perjury, só pode ser alegado contra as testemunhas. Em compensação, a auto-acusação, quer dizer, a negociação da culpa pela admissão falsa de crime menor com o intuito de safar-se de crime maior, é punida pelo Código Penal, o que contrasta tanto com a police bargain, quanto com a plea bargain do sistema judicial criminal dos EUA.

A seguir, "reperguntam-se" todas as testemunhas que já depuseram na polícia, com a assistência oficial e legal da defesa e da acusação. Tal assistência, obviamente, varia de acordo com as posses do acusado e se reflete no comparecimento qualificado - ou na ausência dele - das testemunhas do processo. Por várias circunstâncias (mudanças de residência e/ou de status social e civil, dificuldade de locomoção, doenças, mortes, etc.) são, em geral, as pessoas de melhor condição econômica ou, pelo menos, os réus soltos, que conseguem trazer, de novo, as mesmas testemunhas, assim como outras novas, para depor.

Embora se diga que este processo não é conduzido pelo juiz, mas pelo Ministério Público, não caracterizando, assim, um inquérito judicial propriamente dito, a ênfase no papel do juiz é manifesta, seja na iniciativa a ele atribuída de buscar a verdade real, crível além de qualquer dúvida, seja na condução exclusiva do interrogatório do réu, seja na tomada do depoimento das testemunhas, quando o juiz sempre pode interpretar as respostas dos ouvidos e interrogados ao escrivão, ditando-as ou mandando-as transcrever para registro nos autos.

Durante o processo judicial, o réu pode permanecer preso ou em liberdade. Nos EUA, a fiança é a forma de soltar os réus e aponta-se, por isso, forte discriminação econômica, pois os mais pobres tem sua defesa prejudicada, não só em função de seu pior estado psicológico, como também por não poderem produzir provas para sua defesa. Já no Brasil, nos autos do inquérito policial - em que se registram as investigações contra os mais pobres, feitas sem advogado - os depoimentos e confissões constam dos autos, a eles estão entranhados pela não interrupção da numeração seqüencial de suas páginas, podendo servir ao livre convencimento do juiz.

Além disso, importantes dispositivos legais de diferenciação de tratamento dos acusados, no Brasil, são a "prisão especial", que assegura condições privilegiadas na prisão, concedidas a certas categorias de pessoas, que vão desde a permanência em separado dos chamados "presos comuns" até a "prisão domiciliar", cumprida na residência do acusado; e a "competência por prerrogativa de função", que retira certos acusados do âmbito do juiz singular, enviando-os para julgamento por órgãos judiciais colegiados de instâncias superiores, como os Tribunais de Justiça e os Tribunais Superiores de terceira instância, mesmo no caso de terem cometido infrações comuns.

Finalmente, o juiz decide de acordo com seu "livre convencimento", fundado no conteúdo dos autos, os quais, como apontei, trazem entranhados os registros do inquérito policial, com os depoimentos e confissões obtidas 
na polícia sem a presença oficial da defesa. À literalidade e oralidade dos procedimentos judiciais dos EUA, os procedimentos brasileiros apontam para o privilegiamento da escrita e da interpretação. O juiz, não mais o Estado, é visto como um ser superior, capaz de formular um julgamento racional, imparcial e neutro, que descubra não só a "verdade real" dos fatos, mas as verdadeiras intenções dos agentes. É claro que, como aponta Malatesta, num sistema como esse, somente a confissão pode assegurar ao juiz e ao público o absoluto acerto de sua "sentença".

Nos casos dos crimes intencionais contra a vida humana, no entanto, o juiz singular não dá a palavra final. Nestes casos, ele formula uma sentença que "pronuncia" ou "impronuncia" o acusado. Quando a sentença pronuncia o acusado, seu nome é inscrito no "rol dos culpados", registro do qual só sairá se absolvido no processo. Inicia-se, então o julgamento pelo Tribunal do Júri.

\section{c. O julgamento pelo tribunal do júri}

Embora a maioria da literatura especializada procure estabelecer equivalências entre este nosso procedimento judicial e aquele da tradição angloamericana, tais semelhanças são extremamente superficiais. Para começar, o nosso julgamento não é voluntário, como o do trial by jury, que é aplicado apenas aos que se declararem inocentes. A seguir, porque aqui ele é a culminância de vários procedimentos em que o acusado foi progressiva e sistematicamente acusado, decidindo-se, finalmente, "pronunciá-lo" e inscrever seu nome no "rol dos culpados". A presunção, portanto, é de culpa, não de inocência. Note-se, também, que o due process of law é um procedimento constitucional universalmente disponível aos cidadãos, para ser aplicado de acordo com leis locais, que devem ser a todos os do lugar igualmente aplicadas. A universalidade depende, portanto, da definição do universo, sempre limitado, ao qual se aplica. Em nosso caso, esta é uma instituição judiciária que se aplica apenas a certos crimes, quando se faz a aplicação particularizada de uma lei geral - feita pelo legislativo federal - a casos específicos.

No trial by jury o juiz é o árbitro das regras de admissão de evidências que se apresentam, todas, durante o julgamento. Aqui, o juiz é que está obrigado a procurar, por sua iniciativa, a "verdade real" e se encontra obrigado, pelos critérios da "ampla defesa", à aceitabilidade de todas as evidências e indícios trazidos pelas partes ao processo, sob pena de provocar suas reações, passíveis de prejudicar a validade do processo. O juiz, aqui, lê os autos e os relata para os jurados, que dificilmente tem contato com seu conteúdo de outra forma: seu conhecimento sobre os fatos, enquanto operadores judiciais, portanto, é de segunda ou terceira mão. Também diferem os procedimentos na tomada de depoimentos: nos EUA são feitas questions durante a examination e cross-examination das testemunhas, que não podem ser "interrogadas" quer dizer, não podem ser perguntadas pelo que se supõe que elas sabem, ou deviam saber - nem podem ter suas respostas induzidas; aqui, ao contrário, há um interrogatório obrigatório do réu e não há regras para a tomada de 
depoimento de testemunhas.

Os árbitros, lá, são doze pessoas cuidadosamente selecionados de comum acordo entre defesa e acusação, apenas para aquele julgamento, dentre listas amplas de todos os eleitores ou de todos os residentes. Aqui, são sorteados de uma lista preparada anualmente, de antemão, pelo juiz, da qual se sorteiam vinte e um por mês e, destes, sete para cada julgamento.

O julgamento, aqui, verifica-se, em geral, em uma sala especialmente preparada, diante de uma platéia, que se senta de frente para o juiz, sobre cuja cabeça está, tradicionalmente, um crucifixo católico, representando a humanização da justiça. O promotor localiza-se, ora à direita, ora à esquerda do juiz, de frente para a platéia, e um escrivão senta-se do outro lado do juiz. Sentados em duas filas, junto a uma parede lateral, ficam os jurados, geralmente vestidos com uma espécie de pequena beca, à maneira dos outros serventuários da justiça. Junto à parede oposta, de frente para os jurados, senta-se o advogado, acima do réu, acomodado, também diante dos jurados, no chamado "banco dos réus".

Embora possa apresentar variantes, dependendo das orientações particulares de cada Juiz Presidente do Tribunal do Júri e da época em que o espaço do Tribunal foi construído, esta disposição inquisitorial do espaço contrasta fortemente com disposição adversarial do trial by jury, onde o acusado e sua defesa sentam-se lado a lado à acusação, de frente para o juize de costas para a platéia, tendo a um de seus lados os jurados, sentados na jury box. Caracteriza-se, assim, espacialmente, a igualdade ideológica entre as partes, considerando-se a promotoria como uma parte igual às outras, o que reforça a presunção ideológica de inocência, só passível de alteração por uma reasonable doubt (dúvida razoável), reconhecida pelos jurados.

No Brasil, o julgamento se inicia, após o sorteio e o compromisso dos jurados, por novo interrogatório do acusado. Após este procedimento, podem-se ouvir novas testemunhas, o que dificilmente ocorre, a não ser em julgamentos muito especiais. Dificilmente se ouvem, outra vez, as antigas - a não ser que tenham sido convencidas a mudar de opinião, pois há uma crença generalizada de que elas tendem a "atrapalhar" a argumentação de advogados e promotores, "confundindo" os jurados.

A parte mais importante do julgamento, portanto, é um debate, em que acusação e defesa se defrontam, durante duas horas, cada uma, com a possibilidade de prorrogação por mais uma hora, cada. Nesta verdadeira disputatio escolástica, os advogados e os promotores defendem "teses" opostas, que não podem encontrar-se jamais, sob pena de declarar-se "inepta" a defesa. Quer dizer, mesmo quando acusação e defesa concordam com a culpa ou com a inocência do acusado, têm que acusá-lo e defendê-lo em público, apresentando-se suas teses em oposição. A verdade, assim, não é construída a partir de um consenso, mas aparecerá com o resultado de um duelo, em que vencerá o mais forte, ou o escolhido.

Os advogados também não costumam se ater aos autos, pois não 
ficam registros escritos de suas falas, diferentemente do procedimento dos EUA. Também podem mentir, pois estão sustentando a versão de um acusado que tem direito de continuar a mentir em causa própria durante seu novo interrogatório. Por isso, o conteúdo dos autos, embora lido em suas principais partes pelo juiz, em seu relatório, é posteriormente manipulado livremente tanto pela acusação quanto pela defesa.

Após este verdadeiro espetáculo quase-teatral, os jurados se recolhem a uma sala secreta, sem a presença do réu, na companhia do juiz, de um serventuário da justiça, de representantes da defesa e da acusação - o que difere da reunião secreta para discussão do processo e negociação do verdict dos doze jurados nos EUA, à qual ninguém pode assistir - e, proibidos de discutir entre si, votam de acordo com sua consciência - e inspirados pela imagem de Cristo - respondendo sim ou não a uma série de perguntas extremamente técnicas que incluem o exame de agravantes e atenuantes, formuladas pelo juiz com a anuência da acusação e da defesa (a quesitação), diferentemente do guilty/not guilty da arbitragem dos EUA.

Mais uma vez, o ritual da produção da verdade se revela distinto. Diferentemente da incomunicabilidade dos jurados dos EUA, que podem ser segregados para não se comunicarem com os outros segmentos da sociedade, mas que devem formar sua opinião, sua verdade, em conjunto, pelo consenso, muitas vezes de unanimidade obrigatória, de doze pessoas, aqui a justificativa para a incomunicabilidade dos jurados entre si é a de que as pessoas, sozinhas, decidem melhor do que em conjunto, pois em conjunto podem influenciar-se uns aos outros, o que sempre degradará a qualidade de uma decisão coletiva, formulada por pessoas de antemão selecionadas pelo juiz como aptas para o exercício dessa "nobre" função. Por isso, a votação é secreta e o número de jurados é ímpar. Esta argumentação é tirada das teorias sobre a psicologia das multidões, que tendiam a ver o júri como um tipo desses aglomerados incontroláveis. Lá, a origem da decisão é um grupo que deve resolver suas diferenças internamente para exprimir-se coletivamente; aqui, o grupo é um conjunto de indivíduos selecionados, que devem manter suas diferenças substantivas para exprimir-se mais adequadamente, de acordo, unicamente, com sua consciência individual e inspirados pelos valores cristãos.

\section{Conclusão: a "desqualificação" sistemática enquanto estratégia de controle social diferenciado}

Ora, inicialmente, fica claro com esta rápida descrição que os procedimentos criminais de produção da verdade, no Brasil, não nascem de uma negociação, que resolve conflitos para produzir novos contratos de ordenamento social, mas pretendem se fundar em uma descoberta da verdade, tarefa que se impõe para a produção da ordem social pela conservação da harmonia em sociedade. Tal harmonia deve ser garantida por uma espécie de estratégia de suspeição sistemática, exercitada ora pela autoridade policial, 
em nome do Estado, ora pelos serventuários e operadores judiciais.

Por outro lado, há uma ambigüidade implícita no sistema, que resulta no uso alternado e alternativo de várias lógicas judiciais, que se apresentam diferentemente enfatizadas nas diferentes formas que assumem os procedimentos de produção da verdade judiciária criminal: o inquérito policial enfatiza procedimentos de inquirição, o processo judicial enfatiza procedimentos de inquérito, e o tribunal do júri enfatiza procedimentos do sistema de prova legal, ou de justiça divina.

Assim, podemos dizer que o sistema de produção de nossa verdade judiciária criminal não é universal nem unívoco, como afirmam muitas vezes os que o descrevem, teoricamente. Pois não só os princípios de produção da prova são distintos, como também aplicam-se diferentemente a tipos de crimes e de criminosos. Os procedimentos judiciários da polícia se encarregam das investigações sigilosas e preliminares dos crimes e da sua negociação, visando ou sua solução definitiva pela confissão e, posteriormente, seu abafamento, pela repreensão dos conflitos menores - como era o caso dos "crimes de polícia”, no tempo do Império; ou o indiciamento e envio à justiça dos crimes mais graves ou daqueles - em geral denominados de "criminosos frios e calculistas" - que resistiram à tortura judiciário-policial, ou que se encontram fora do alcance dela em função de sua posição social.

Já o processo judicial se encarrega dos "crimes profissionais", cometidos por aqueles que se dedicam a estas atividades como meio de vida; $\mathrm{e}$ o "Tribunal do Júri" se especializa nos "crimes passionais", teoricamente cometidos em defesa da honra e julgados pela justiça divina, expressa na iluminação da consciência individual dos jurados, sem levar em consideração testemunhos ou fatos do processo. Em ambos os casos, a justiça distingue explicitamente entre os acusados, dando-lhes tratamento diferenciado de acordo com sua classe social.

O contraste com o sistema dos EUA também aponta para uma diferente relação interna entre os operadores do sistema: se lá há uma rivalidade entre acusação e defesa na construção de duas versões que se baseiem em fatos consensuais, decididos em um procedimento controlado por regras estáveis, negociadas e explícitas, há um enfrentamento - chamado de adversarial - durante a arbitragem, entre acusação e defesa, não se permitindo o fracionamento de nenhum desses agentes do processo. Há também uma tensão entre o Distric Attorney e a polícia, de um lado, e o judiciário, do outro, pelo monopólio da negociação da verdade. Entretanto, o sistema tende a solucionar pela via da negociação todos os conflitos que a ele se apresentam.

O sistema brasileiro, ao enfatizar distintas lógicas em procedimentos judiciários hierarquizados diferentemente, incentiva a competição interna pela "melhor" verdade e termina por produzir uma progressiva desqualificação de um sistema sobre o outro. Assim, os conflitos não tendem a ter solução consensual, pois as diferentes verdades foram produzidas de acordo com diferentes critérios de validade, todos legítimos diante do próprio sistema. O que 
os une, então, não é a lógica comum da produção da prova, mas o "ethos" da suspeição e da punição sistemática - ou do perdão/absolvição dos acusados cujas "intenções" acabam por valer mais que seus atos.

Em conseqüência, desqualificam-se, reciprocamente, os operadores do sistema, rotulando-se reciprocamente, por exemplo, de advogados "de porta de cadeia", aqueles especialistas em negociações com a polícia; de "advogados de foro", aqueles especialistas nos procedimentos, na maioria informais, dos cartórios do foro, onde se julgam os crimes profissionais; em "advogados de júri", também versados no trato dos cartórios do júri mas, pricipalmente, treinados na representação e na mentira pública, na sustentação da versão de seus clientes durante o duelo, ou ordálio, do júri brasileiro. $\mathrm{O}$ mesmo ocorre entre promotores e juízes, cada um a "defender" ou a "atacar" o sistema de produção da verdade que não lhe convence.

Mais dramática, no entanto, é a situação da polícia: encarregada de descobrir a verdade além de qualquer dúvida, expressa na confissão, vê suas descobertas, validadas pela forma da inquirição a que está submetida, serem derrubadas quando submetidas, posteriormente, aos critérios do processo judicial, ou do júri. Situada no lugar mais inferior deste sistema hierárquico, sua verdade também é a que menos vale. Entretanto, não se deve esquecer que é ela que se defronta, no dia a dia, com a população, impregnando-a e por ela sendo impregnada com seus critérios de justiça e de verdade, ao mesmo tempo em que assume, cada vez mais, sua degradação institucional.

A estes problemas acresce o caráter "real" da polícia, tanto militar como civil, no Brasil e no Rio de Janeiro: desde D. João VI, cuja coroa enfeita o brasão de nossa PMERJ, até o ethos repressivo que permeia nossa Polícia Civil, está, sempre, a polícia, a serviço do Rei, do Estado, para conciliar forçadamente ou para reprimir conflitos e não para resolvê-los, garantindo a ordem estatal pública e, não, negociando e disciplinando, preventivamente, a ordem dos cidadãos.

Internamente dividida em "delegados" e "tiragem", cujas diferenças salariais são assustadoras para o tipo de tarefas comuns que têm por dever exercer, mas que os delegados justificam, na prática, por serem formados em direito e, assim, poderem operar a tradução entre os dois regimes de verdade, o policial e o judicial; opostos os "tiras" em "turma da rua" e "turma do cartório", conforme se encarreguem de investigações ou de registros cartoriais, o que define diferentes formas e oportunidades de negociação e remuneração, sempre oficiosas ou ilegais; dividida também a Polícia Militar em estanques categorias de "oficiais" e "praças", tendem estas instituições a reproduzir esta incomunicabilidade de critérios internamente, enfatizando formas de socialização informal, não escolar, que produzam e reproduzam socialmente os métodos de produção da verdade a serem exercitados pela corporação. Diferentemente da polícia de outros países, em que, se a "teoria na prática é outra", as duas dimensões se referem ao mesmo regime de verdade, aqui a polícia se move em um outro espaço, "inferior" e controlado por outros princípios. 
A esta "distonia cognitiva", em todas as instituições e níveis, corresponde uma valorização extrema dos intermediários, dos despachantes, alcagüetes (X-9s), serventuários da justiça, em especial funcionários cartoriais, que se encarregam de ensinar as diferentes lógicas, implícitas nas práticas judiciárias, a serem apreendidas, caso a caso, aos operadores, que demandam por eficácia em seus atos junto a sistemas de verdade que possuem diferentes regras, todas também implícitas, de validação.

Entretanto, esta desqualificação, produzida pelos estilos profissionais respectivamente apropriados para o bom exercício da produção da prova nos diferentes sistemas, não tem apenas consequiências internas ao sistema: o próprio sistema, à luz da sociedade como um todo, perde legitimidade, porque o que vale para um caso e para um agente/acusado não vale para outro.

Por outro lado, o uso alternativo dos sistemas caracteriza a tolerância do sistema com a particularização da aplicação da lei geral. Esta é própria não só das sociedades mediterrâneas e tradicionais, onde na busca da verdade e das intenções competem diferentes sistemas de honra, que exigem a punição diferenciada do conflito, mas também da codificada civil law tradition, que tem suas disposições gerais elaboradas pelo legislativo, no qual os representantes do povo pretendem controlar o arbítrio do executivo e do judiciário, que devem limitar-se, respectivamente, a executá-las e a aplicá-las a casos particulares.

Entretanto, esta tradição particularista se opõe, aparentemente, aos anseios de universalidade de uma cultura política explícita, de caráter individualista e igualitário, que precisa fundar-se em mecanismos de resolução de conflitos pela produção de verdades negociadas. A tensão entre o político e o jurídico, assim, cada vez mais, se faz presente em nossa sociedade, opondo uma concepção de generalidade fundada em diferenças substantivas entre as pessoas e as coisas, próprias dos sistemas hierárquicos e particularistas, a uma universalidade fundada na aplicação local de regras consensuais e na estratificação das igualdades formais, própria dos sistemas individualistas.

Espero que este contraste entre formas, sistemas e regimes de produção de verdades contribua para esclarecer alguns aspectos das possíveis dificuldades de diálogo entre cientistas sociais e juristas, no Brasil e nos EUA. Pois, enquanto nos EUA as ciências sociais e o direito têm modelos análogos de construção e legitimação de seus saberes, o que os levou à disputa litigiosa por objetos de investigação, como aconteceu com diferentes aspectos do trial by jury system, este não é o caso, no Brasil. Se aqui as Ciências Sociais, atualmente, enfatizam modelos de construção de conhecimento que buscam o consenso, tornados universais na academia e no judiciário dos EUA, o direito brasileiro enfatiza processos de produção, reprodução, legitimação e consagração do conhecimento análogos às formas judiciárias vigentes para a produção da verdade jurídica brasileira.

Assim, o que é verdade para os cientistas sociais não o é, necessariamente, para os juristas. Estes reproduzem em seus encontros e no ensino 

de 1997.

do direito as formas escolásticas que privilegiam os argumentos de autoridade e os debates em que ou uma tese, ou outra, ganha - e, logo, se "prova" verdadeira. A isto se opõe a preocupação com as demonstrações de fatos consensuais, fundadas na autoridade dos argumentos, próprias das ciências sociais. A consciência dessas diferenças, ao invés de torná-las intransponíveis, deveria desafiar-nos a superá-las, em nome de nossa vontade política de construir uma sociedade mais justa para nós mesmos e para nossos concidadãos, só alcançável quando houver uma ampla e esclarecedora discussão sobre as formas de construir a verdade e administrar conflitos em nossa sociedade.

Recebido para publicação em janeiro/1997

KANT DE LIMA, Roberto. Police and exclusion in the judiciary culture. Tempo Social; Rev. Sociol. USP, S. Paulo, 9(1): 169-183, May 1997.

ABSTRACT: The objective of this paper is show that the institutional role of the police is influenced by the view that the police institution develops formally and unformally in the judiciary system. Opposite to the conceptions which thinks that the police is in charge for the social preventive control and so, been autonomous in front of the Public Prosecutor and the Judiciary, it will al be shown that this institutional role is related to different ways of producing judiciary

UNITERIMS: police organization, judiciary system, culture, social control, police inquiry, judicial inquiry. trues to the judiciary system of each country. 